\title{
The Processes of Defining Corporate Responsibility: A Study of Swedish Garment Retailers' Responsibility
}

\author{
Jenny Ählström* \\ Sustainability Research Group (SuRe) \\ Department of Marketing and Strategy \\ Stockholm School of Economics \\ BOX 6501 \\ SE - 11383 Stockholm, Sweden \\ Jenny.Ahlstrom@hhs.se \\ +46-8-7369559 (telephone) \\ $+46-8-334322$ (fax) \\ Niklas Egels-Zandén \\ Centre for Business in Society \\ School of Economics and Commercial Law at Göteborg University \\ SE - 40530 Göteborg, Sweden \\ Niklas.Egels-Zanden@ handels.gu.se \\ +46-31-7732729 (telephone) \\ +46-31-7721237 (fax) \\ * Authors are listed in alphabetical order and have contributed equally to this paper. The \\ majority of the interviews were conducted by Jenny Ählström.
}

Forthcoming: Business Strategy and the Environment 


\title{
The Processes of Defining Corporate Responsibility: A Study of Swedish Garment Retailers' Responsibility
}

\begin{abstract}
Despite extensive research on corporate responsibility, little research exists on how the inter-organisational processes of defining corporate responsibility develop. In this paper, we present a framework based on Actor-Network Theory (ANT) for analysing these processes. The developed framework is illustrated in a study of the redefinition of Swedish garment retailers' responsibilities for workers' rights at suppliers' factories between 1996 and 2004. We show that definition processes can be characterised as battles for the right to interpretation, and that traditionally non-dominant actors can, at least temporarily, win these battles and dictate the development of the processes for defining corporate responsibility. We also show that definition processes can take an exclusionary form prohibiting certain actors from participating.
\end{abstract}

Key words: actor-network theory, ANT, codes of conduct, corporate responsibility, CSR, garment industry 


\section{Introduction}

Extensive normative research exists on how corporations ought to act and on how corporate responsibility should be defined (e.g. Carroll, 1979; Donaldson and Preston, 1995; Gladwin et al, 1995). Research also exists on firms' social performance in specific areas of responsibility, i.e. how corporate responsibility is defined at specific times (e.g. Arlow and Gannon, 1982; Cochran and Wood, 1984; Waddock and Graves, 1997), and how the intra-organisational firm processes leading to particular definitions of corporate responsibility develop (e.g. Schwartz, 1997; Schaefer and Harvey 1998; Strannegård, 2000). Despite this extensive research on corporate responsibility, little research exists on how the inter-organisational negotiations, conflicts and collaborations leading to a particular definition of corporate responsibility develop (for exceptions see Sweet, 2000; Hoffman, 2001; Hoffman and Ventresca 2002; Ählström, 2003). Thus, the inter-organisational processes for defining, and redefining, corporate responsibility have remained somewhat unexplored. As Newton (2002) and Rowley and Berman (2000) notice, we have limited knowledge of how the existing order of corporate responsibility is created. A review of the last ten years of publications in Business Strategy and the Environment confirms this picture with only about a handful of articles exploring the inter-organisational processes leading to particular definitions, and redefinitions, of corporate responsibility (notable exceptions include Neale 1997; Boons 1998; Clarke and Roome 1999; Canning and Hanmer-Lloyd 2001; Harrison and Easton 2002).

The purpose of this paper is to begin to fill this identified research gap by analysing how the inter-organisational processes of defining, and redefining, corporate responsibility actually develop. Such research is of importance if we are to understand how and why certain, and not other, definitions of corporate responsibility become established in a society where no business, government, civil society or union organisation in isolation is able to define corporate responsibility. We outline a framework for describing and analysing these inter-organisational processes by building on Actor-Network Theory (ANT), and propose that ANT provides a promising theoretical resource for this type of research. Based on the developed framework, we generate three research questions: a) how can the processes of defining corporate responsibility be characterised, b) what actors dictate the development of the processes of defining corporate responsibility and c) what actors are excluded from the processes of defining corporate responsibility? These questions are analysed in a study of the processes leading to a redefinition of four large Swedish garment retailers' responsibility for workers' rights at their suppliers in developing countries between 1996 and 2004.

The previous research on inter-organisational processes of defining corporate responsibility is mainly based on institutional theory (e.g. Hoffman, 1999, 2001; Hoffman and Ventresca, 2002). Although there is no inherent conflict between actornetwork theory and institutional theory and authors previously have combined them (e.g. Czarniawska and Sevón, 1996), ANT has a stronger focus on: a) power, b) micro level processes and c) qualitative research methods. First, while institutional theory has been criticized for paying limited attention to power relations (e.g. DiMaggio and Powell, 1991; Blomquist, 1996; Beckert, 1999; Maguire et al, 2004), ANT is essentially about analyzing how power, in practice, is constructed (Latour, 1991; Czarniawska and Hernes, 2005). Second, ANT is micro oriented and focused on following individual 
actors' actions (Callon and Latour, 1981), while institutional theory is more macro oriented as, for example, exemplified in the focus on organisational fields (e.g.

DiMaggio and Powell, 1983, 1991; Hoffman 1999; Morrill and Owen-Smith 2002).

Third, this micro/macro difference has led ANT research to employ qualitative research methods focused on analyzing processes (e.g. Callon, 1986a, 1986b), while researchers

using institutional theory tend to employ more quantitative methods focused on patterns in cross-sectional data (e.g. Scott 1995; Hoffman, 1999; Jennings et al, 2002; Milstein et al, 2002; Morrill and Owen-Smith 2002; Scheiberg and Clemens 2005). Hence, ANT and institutional theory yield different research focuses and questions in relation to definitions of corporate responsibility with ANT being more focused on questions related to: a) the role of individual actors in the definition processes, and b) the inclusion and exclusion of individual actors in these processes. Therefore, the introduction of ANT into research on corporate responsibility provides a valuable compliment to current theoretical approaches.

\section{Actor-Network Theory}

\section{Fact-establishing}

Actor-Network Theory (ANT) deals with how the processes of establishing facts and definitions develop. More specifically, ANT aims to analyse the discussions, controversies and negotiations that forego an establishment of 'facts'. Previously, the framework has primarily been used to analyse the establishment of scientific facts (e.g. Latour and Woolgar, 1979; Law, 1994; Latour, 1999a), markets and economic facts (e.g. Callon, 1998a; Callon, 1998b; Helgesson and Kjellberg, 2004), facts related to information systems (e.g. Mähring et al, 2004; Holmström and Robey 2005; Lanzara and Morner 2005; Norén and Ranerup 2005; Porsander 2005) and the definition of the term sustainability (Gollagher, 2003). This paper will utilise the ANT framework for analysing the processes of establishing yet another type of 'fact', i.e. firms' responsibilities for workers' rights at their suppliers.

There seems to be growing recognition for the potential of using ANT in studies of corporate responsibility (Stubbs 2000; Newton 2002). Newton (2002:531), for example, recently called for more ANT research on how networks "become standardized around processes that encourage environmental degradation." The author also noted the current lack of application of ANT in green organisational studies. Although, up to the present day ANT has mainly been applied in studies of environmental, rather than social aspects in both general research (e.g. Selman and Wragg 1999a; Selman and Wragg 1999b; Ivakhiv 2002; Van Amerom 2002; Gollagher 2003), and that of corporate responsibility (e.g. Neale 1997; Catasús 2000; Füssel and Georg 2000; Stubbs 2000). Since previous ANT research has given little attention to corporate responsibility issues, and in particular the social aspects of corporate responsibility (for an exception see Egels (2005)), this paper provides an extension of ANT into currently unexplored empirical areas.

\section{Processes of defining facts}

To describe the establishments of definitions and facts, ANT provides the concept of translation (Callon, 1986a; Callon, 1986b). Callon and Latour (1981:279) define translation as "all the negotiations, intrigues, calculations, acts of persuasion and 
violence thanks to which an actor or force takes, or causes to be conferred on itself, authority to speak or act on behalf of another actor or force." Translation, therefore, occurs when an actor manages to persuade (in the ANT terminology enrol) another actor to accept its view of the world (Callon, 1998b). In terms of corporate responsibility, this means that translation occurs when an actor persuades another actor to accept its suggested definition of corporate responsibility. Several successful translations of different actors lead to the establishment of a definition. As a definition stops being questioned, the definition is in ANT terminology black-boxed. "A black box contains that which no longer needs to be reconsidered, those things whose contents have become a matter of indifference" (Callon and Latour, 1981:284). This blackboxing means that the actors participating in the definition processes treat the definition as a 'fact' that is no longer questioned. The black-boxing is preceded by an Obligatory Point of Passage (OPP). An OPP can be seen as a central proposition from an actor that, upon other involved actors accepting it, leads to a change in how 'facts' are defined. An OPP is often, but not always, materialised in a specific event, e.g. the signing of a document or the initiation of a partnership. Based on the process definitions of ANT, the first research question of this paper is: How can the processes of defining corporate responsibility be characterised?

In the definition processes certain actors gain a more influencial role than others. This difference in influence is from an ANT perspective "nothing more than the end-product of processes of translation" (Callon, 1986a:228). A seemingly large actor, i.e. a macroactor, has through the processes of translation grown from a micro-actor by translating and gaining the right to speak on behalf of other actors (Callon and Latour, 1981). The enroled and translated actors have thus, been silenced, and have become pieces of the translating actor's project. Consequently, a macro-actor can be described as an actor seated on numerous silenced and translated actors (Callon and Latour, 1981). Therefore, a macro-actor, from an ANT perspective, is neither different nor necessarily larger than a micro-actor, because its relative power can disappear if the actors it has silenced begin to question the current order, i.e. start to open the black-boxes established by the macroactor. When this occurs, the role and legitimacy of the macro-actor are questioned, and shifts in sizes may potentially occur. Based on this discussion of translation and size, the second research question of this paper is: What actors grow and dictate the development of the processes of defining corporate responsibility by enroling and translating other actors?

A critique of the ANT literature is that it has solely focused on the actors translating other actors (Star, 1991; Lee and Brown, 1994; Latour, 1999b). This has led ANT research to describe and analyse the winner's story, resulting in a marginalisation of the role of the translated actors. Recently, ANT studies have started to deal with this by focusing on the actors excluded from the definition processes. These studies have shown that the story of the so called 'inappropriate others' entails critical information for understanding the definition processes (Haraway, 1992; Haraway, 2003; Palmås, 2005). The third research question for this paper is therefore: What actors are treated as 'inappropriate others' and excluded from the processes of defining corporate responsibility? 


\section{Method}

Studies based on actor-network theory tend to utilise a qualitative research methodology, and collect data mainly from interviews, observations and written sources (e.g. Callon, 1986a; Callon, 1986b). This reliance on qualitative empirical material resounds well with the suggested methods for analysing the emergence of definitions (in this paper the definition of corporate responsibilities) in local contexts (Weick, 1996). Comparable with previous ANT studies, this paper builds on data collected through written documentation and interviews. In total, 29 interviews were made between 2002 and 2004 with 15 key representatives from the two unions (5 interviews), a number of the civil society organisations (12 interviews) and the four corporations (12 interviews) involved in the processes of redefining Swedish garment retailers' responsibilities between 1996 and 2004. Those interviewed were responsible for corporate responsibility issues in their respective organization and personally involved in the redefinition processes. The interviews were semi-structured and lasted on average one hour each. Additionally, secondary information was collected from internal documents, reports, web-pages and newspaper articles. In particular, newspaper articles were useful for analyzing actors' positions during the initial phase of the definition processes (19961999), since garment retailers' supplier responsibilities were highly debated in Swedish media at this time. In comparison, internal documents and reports were more used during the latter phases of the processes (1999-2004), since the definition processes, at these phases, mainly took place behind closed doors.

The collected data were used to construct a chronological representation of the definition processes based on coding conducted by both authors. Through identification of key decision points, this representation was then divided into three main phases. The positions taken by each actor at each decision point was subsequently outlined and the actual decisions' effects on garment retailers' responsibilities described. Based on this, we identified which actors seemed to dictate what decisions. Following this, an earlier version of the empirical section of this paper was sent to the interviewed representatives in order to validate our description of the definition processes. Finally, all the respondents' suggested changes, in total a handful, were incorporated into the final version of the description of the definition processes.

\section{Redefining corporate responsibility for Swedish garment retailers}

\section{The first phases $(1996$ - 1999)}

\section{Initiating Swedish Clean Clothes Campaign (SCCC)}

In 1996, the newly started Swedish Civil Society Organisation (CSO) Fair Trade Center (FTC) came in contact with the Dutch CSO Clean Clothes Campaign. ${ }^{1}$ At this time, FTC had only one employee working full-time, and the organisation had a total of one and a half paid positions. ${ }^{2}$ FTC decided, after discussions with Clean Clothes Campaign, that it should initially focus its resources on improving workers' rights at suppliers to the Swedish garment retailers. The first step in this was for FTC to start a Swedish

\footnotetext{
${ }^{1}$ The Clean Clothes Campaign started in the Netherlands in 1990 with the aim of improving workers' rights in the garment and sportswear industry.

${ }^{2}$ FTC started with the aim of working for fairer trade between Swedish firms and individuals and organizations in developing countries.
} 
Clean Clothes Campaign (SCCC), and through SCCC persuade firms to take responsibility for workers' rights at their suppliers in developing countries.

The people at FTC started to contact individuals in their personal networks in Swedish CSOs, in order to build support for SCCC. Most of the individuals contacted then persuaded their organisations to join the SCCC. Simultaneously, FTC, together with representatives from the Dutch Clean Clothes Campaign, contacted the two Swedish unions involved in the garment retailing industry to persuade them to join SCCC. Although the unions had some experience of working with workers' rights in developing countries, they had not had any previous collaboration with CSOs concerning these issues. The unions claimed not to have known their position at this time. However, they were impressed by the drive of FTC and sympathised with the goal of the campaign. After internal discussions, both the unions decided to join the network and this led to the forming of SCCC. The founded SCCC served as an umbrella organisation for FTC, the two unions and CSOs (Red Cross Sweden Youth, Swedish World Shops' Association, SAC Syndicalists, Global Publications Foundation, Emmaus Stockholm and Swedish Cooperative Center and Förbundet Vi Unga). The core of SCCC consisted of a working group with four members - one each from FTC, the two unions and one of the other CSOs. As the initiator of SCCC and a member of the working group, FTC held a strong position in SCCC. According to the unions and the other CSOs, FTC was also the actor proposing all of the ideas on how SCCC should proceed.

By proposing the formation of SCCC, FTC created - in ANT terminology - an Obligatory Point of Passage (OPP). FTC chose which organisations could join the network, and it then became a 'fact' that the organisations in SCCC would work to define Swedish garment retailers' corporate responsibility, i.e. FTC had established a 'black-box' regarding the organisations that should be involved in the definition processes. Actors not included in SCCC were consequently excluded and silenced from the forthcoming definition processes. FTC also managed to obtain an influencial position - both formally and informally - in SCCC that consisted of several other larger CSOs and unions. In essence, FTC had started to grow into a macro-actor by commencing the translation and silencing of the voices of Swedish unions and CSOs.

Pressuring firms to develop codes of conduct

As a first SCCC activity, FTC proposed the initiation of a post card campaign aimed at four of the largest garment retailing firms in Sweden: Hennes \& Mauritz (H\&M), Lindex, KappAhl and Indiska. ${ }^{3}$ The reason for choosing these four firms was that they were Swedish retailers' most recognisable brands. By influencing their behaviour, FTC wished to start a chain of reaction throughout the entire Swedish garment retailing industry. The other organisations in SCCC accepted FTC's suggestion, and in 1997 post cards with the following text were distributed to consumers all over Sweden with the aim of their sending them to the four firms:

\footnotetext{
${ }^{3}$ In total H\&M, Lindex, KappAhl and Indiska had a turnover of 64,000 million SEK in 2004 (approximately 9,000 million USD) and directly employed over 35,000 people world-wide plus numerous thousands indirectly in their supply chains.
} 
I would like to have more information about the working conditions and the working environment for the people who make your garment. I would also like to know how your suppliers are following the ILO conventions on human rights at the workplace. I would buy more from you if I knew that your garment was produced under decent conditions.

FTC's purpose with the post card campaign was to put pressure on the chosen firms in order to broaden their responsibilities in terms of workers' rights at their suppliers' factories in developing countries. Despite previous international 'scandals' during the 90's concerning workers' rights in, for example, Nike's, Levi's and GAP's suppliers' factories, few claims had previously been raised in Sweden about Swedish garment retailing firms' responsibilities for their suppliers' actions. Through SCCC and the post card campaign, FTC, thus tried to change this and to redefine and widen the retailers' responsibilities.

Parallel to the post card campaign, SCCC also contacted the four chosen firms both in writing and over the telephone urging them to adopt codes of conduct. Once again, it was FTC who set the agenda for how SCCC was to act. FTC had picked up the idea of codes of conduct from the international Clean Clothes Campaign, and the international discussions in the garment and related industries. At this stage, FTC had formulated a problem - workers' rights in suppliers' factories are poorly protected - and a solution to the problem was that through codes of conduct this would change.

In the end of 1997, SCCC held discussions with each of the four firms and discussed the adoption of codes of conduct. The firms were probably taken by surprise by the critique and wanted to find a 'solution' to the issues of workers' rights minimising goodwill losses from negative media attention. This marked a radical change in how the retailers expressed their responsibilities - now publicly announcing a responsibility for workers' rights at their suppliers' factories. Furthermore, the firms came to accept FTC's proposed tool, i.e. codes of conduct, as the way of operationalising this widened responsibility.

FTC's proposition for codes of conduct can be seen as a second Obligatory Point of Passage, that would - upon acceptance - lead to a redefinition of how corporate responsibility was defined among garment retailers. The issue of if firms were responsible was no longer a question for debate, as both the other organisations in SCCC together with the firms accepted FTC's proposition. It was established as 'fact' that Swedish retailers were responsible for workers' rights at their suppliers, and that codes of conduct should operationalise this responsibility. FTC had thereby black-boxed these issues. However, what was yet to be resolved was the question of the content of the codes of conduct, and of the way in which the codes were to be monitored.

\section{Enroling firms to SCCC collaboration}

In the spring of 1998 when the firms had adopted codes of conduct, FTC realised that there were two main problems remaining. First, because the firms had different codes of conduct, it would be difficult for a supplier of more than one firm to keep track of all of the codes. Although much of the codes' content was based on what FTC previously had proposed, there were some important differences between the firms' codes. Second, it would be difficult for the firms to credibly monitor the implementation of their own 
codes. Then, FTC through SCCC proposed that the firms should harmonise their codes, and develop an independent monitoring system, in order to deal with these problems. Initially, the firms were reluctant to accept the new demands. For example, the firms claimed that independent monitoring was difficult due to transparency problems, i.e. they were hesitant to reveal what suppliers they utilised in order to support independent monitoring.

At the end of 1998, the firms retreated from this position and decided to accept FTC's proposed definition of their responsibility, and joined a SCCC initiated collaboration in an effort to harmonise codes and develop an independent monitoring system. The firms' involvement in the SCCC collaboration (later labelled DressCode ${ }^{4}$ ) can be seen as the third Obligatory Point of Passage established by FTC. In this OPP, the ideas of harmonised codes of conduct and independent monitoring were established as 'facts' and became black-boxed.

\section{Initiating DressCode}

An initial difficulty for the launch of DressCode was to find funding for the project. Initially, SCCC tried to receive funding from SIDA (the Swedish government's donor agency). However, this failed and the companies decided to provide financing for the first three years of the project. In 1999, the project was officially launched by SCCC and the four firms involved. The project ran quite rapidly into problems when one of the CSOs involved in SCCC - SAC-Syndicalists - wanted to initiate yet another public campaign against the four firms. This was seen as problematic, since the involved organisations had agreed to coordinate activities about social responsibility in the garment industry through SCCC. A decision was taken that SAC-Syndicalists would leave the project, since it was not possible to harmonise SAC-Syndicalists' and the DressCode project's working methods. After resolving these initial problems, the project DressCode commenced. FTC had, with the initiating of DressCode, created a fourth Obligatory Point of Passage. In this OPP, the 'fact' that a harmonised code and independent monitoring system were to be developed in close partnership (funded by the firms) was established and black-boxed.

\section{The second phase $(1999$ - 2001)}

\section{Dress Code: A common code}

The DressCode project had two main purposes. First, the project aimed at creating a common standard code of conduct for the four participating firms and, second, the project aimed at developing an independent monitoring system. Much of the initial effort of the project was directed at the first aim of creating a common code of conduct. FTC proposed a code of conduct containing ILO core conventions, UN declarations of human rights and "living wages" ${ }^{5}$. All the CSOs involved in DressCode accepted and supported FTC's suggestion. However, the firms were reluctant to accept living wages and argued that these were difficult to calculate, and that a change from 'minimum wage' would mean that they had to renegotiate all their supplier contracts. Following

\footnotetext{
${ }^{4}$ Even though most actors refer to the project as 'DressCode', the union representatives claim not to have agreed to adopt this project name.

5 'Living wage' is the salary level covering all basic needs and 'minimum wage' is the lowest legal salary level in the country.
} 
some discussions, FTC and the other CSOs decided to accept the firms' proposition of minimum wages and retreated from their original position. This led to the creation of a common code of conduct containing ideas from both FTC and the firms. This code represents the fifth OPP in the definition processes, and was accepted by all involved actors. A new detailed and documented definition of the garment retailers' responsibility had now been established and black-boxed. The question now remaining was how to implement the developed definition in practice.

\section{DressCode: Independent monitoring}

Initially, the organisations in DressCode evaluated whether or not the firms' own monitoring systems could ensure the implementation of the developed code of conduct. The result of this evaluation was clear - according to all project members the companies' monitoring systems were inadequate. In order to overcome the identified problems with companies' monitoring systems, pilot tests with different types of monitoring were conducted in three developing countries. After approximately two years of studies, a proposition was presented in the form of a monitoring foundation supported by Swedish CSOs and unions that was primarily based on FTC's and the firms' ideas. The foundation would own a non-profit organisation, which would sell independent monitoring to garment retailers. The 'independent' monitoring foundation represented the sixth OPP proposed by FTC and the firms. Upon acceptance, this proposition would have black-boxed the question of how the independent monitoring of the developed code of conduct was to be designed. At the end of phase two, a detailed operationalisation of the firms' redefined responsibilities, and a detailed suggestion for monitoring, had been developed.

\section{The third phase $(2002-2004)$}

\section{The end of DressCode}

In 2002, it became clear that the proposed independent monitoring foundation was not going to be realised, i.e. the sixth OPP was not going to be passed, due to the unions leaving the DressCode project. The unions stated several reasons for their withdrawal. First, they claimed that the suggested code of conduct was unacceptable, since it did not include all of the ILO-conventions. Second, they claimed not to believe in codes of conducts as a way of operationalising corporate responsibility. Instead, they wanted to enter into binding global collective agreements with the firms. Third, they stated that they did not perceive themselves as having the mandate to enter into agreements on behalf of the workers in developing countries. All of these reasons had one thing in common - they opened black-boxes and questioned 'facts' that had been established in previous OPPs.

The first reason presented by the unions (unacceptable content of the developed code) opened the black-box of the developed definition of corporate responsibility established in the fifth OPP. Suddenly, the unions wanted to redefine the content of the developed codes and, therefore challenged the previous definition created by FTC and the firms with the, at least implicit, consent of the unions. The second reason (global collective agreements rather than codes of conduct) opened the black-boxes established in the fourth, third and second OPP. If the unions did not believe in codes of conduct, then there was no need for a DressCode project funded by the firms (forth OPP), no need for 
a harmonised code and independent monitoring (third OPP), and thus there was obviously no agreement on codes of conduct as the way of operationalising retailers' widened responsibility for suppliers (second OPP). Finally, the third reason (no mandate to negotiate) opened the black-box established in the first OPP, i.e. that SCCC consisting of Swedish CSOs and unions should dictate how the garment retailers' responsibility was to be defined. Rather than SCCC being the organisation for the firms to negotiate with, the unions claimed that the negotiations should ultimately be carried out by the workers in the developing countries through local and national unions. In essence, all that remained after the unions' critique was one of the black-boxes established at the second OPP, i.e. the 'fact' that Swedish garment retailers are responsible for some vague notion of workers' rights at their suppliers. The unions had thereby challenged almost all the 'facts' that FTC and the firms had worked for establishing between 1996 and 2001.

The unions' withdrawal and critique was not taken lightly by FTC, the other CSOs and the firms. Critical voices were raised, both unofficially and in the Swedish media, claiming that the unions had previously agreed to all of the aspects they now claimed not to support. This critique seems to quite accurately describe what happened in the process. So why then did the unions make such a change? The main reason for this change seems to have been that the international unions, particularly the International Textile, Garment and Leather Workers' Federation (ITGLWF), had taken a much stronger position in terms of workers' rights in developing countries in 2001-2002 than previously. In the same way as the Swedish unions did not know their position regarding codes of conduct during the 1990's, the international unions had given these issues limited thought and interest. However, in 2001 ITGLWF had taken a policy decision not to support codes of conduct. Particularly the manager of this federation, a highly respected man within the Swedish unions involved in DressCode, had fiercely argued this point. One of the two Swedish unions involved in DressCode was one of the about 200 affiliated organisations of ITGLWF, or if we like one of 200 'owners' of ITGLWF, and had thus also participated in electing the current manager of ITGLWF. The role of ITGLWF was to coordinate the different national unions and advice in policy decisions. Given the strong emphasis on solidarity in the union movement, it seems to have been difficult for the Swedish unions to actively support DressCode when their international policy setting organ had decided not to support codes of conduct. Hence, the Swedish unions got disenroled from the DressCode actor-network and enroled in another actor-network led by ITGLWF. After the unions' withdrawal, the CSOs including FTC, decided not to create the independent monitoring foundation. They did not feel comfortable implementing the suggested code and control structure without the support of the unions. Therefore, the DressCode project came to an end in 2002.

\section{After DressCode}

The collapse of DressCode meant that almost all of FTC's translations of actors and black-boxing between 1996 and 2001 had been reversed, and the garment retailing industry almost returned to its initial position in 1995 (albeit with firms, NGOs and unions gaining several years of learning experiences). However, one major change had occurred. The firms now publicly claimed to be responsible for workers' rights at their suppliers. Although, what this meant in practice, and how it was to be implemented was 
unclear. The progressing consensus that FTC and the firms had directed between 1996 and 2001 was demolished, and 'facts' were once again up for grabs.

The unions started, and are still trying, to enforce their 'solution' - that global collective agreements should define firms' responsibilities, and that local unions should monitor the implementation of these definitions. However, the firms perceived this solution as unrealistic given the low level of unionisation in the regions in which they operate. Instead, the firms mainly explored other solutions. H\&M worked with their own code of conduct and monitoring, and have also started discussions with Fair Labor Association (FLA) and Fair Wear Foundation for possible future collaborations. KappAhl worked with their own code of conduct and monitoring, collaborated with the Norwegian Ethical Trading Initiative (IEH) and made SA8000 inspections at some of their suppliers' factories. Indiska and Lindex focused on their own codes of conduct and monitoring. However, none of these firm driven projects have yet succeeded in stabilising a definition of garment retailers' responsibilities, and the unions and CSOs have continued to critique the firms' actions. Lindex and KappAhl are now taking part in Business Social Compliance Initiative (BSCI) - an initiative formed by European garment retailers. The aim of BSCI is to develop a standardised code of conduct and monitoring system for the garment industry. Thus far, H\&M and Indiska have decided not to take part in BSCI.

\section{Summary}

We can now summarise the evolutionary processes of defining Swedish garment retailers' responsibilities for workers' rights at their suppliers between 1995 and 2004. Figure 1 below illustrates these processes.

Year

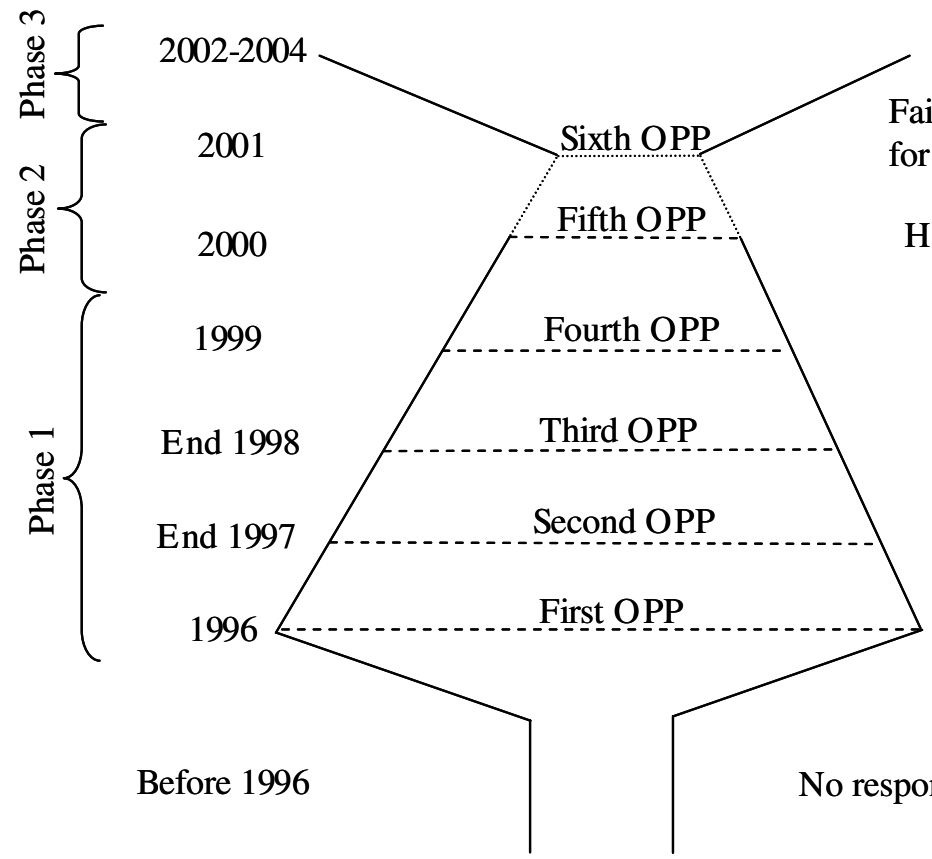

Interpretation span of retailers' responsibility
'Facts'black-boxed

Failed black-boxing of system for independent monitoring

Harmonised code of conduct

Partnership project

Harmonised codes with independent monitoring Responsibility for workers' rights through codes of conduct Actors allowed to participate in the process (SCCC)

No responsibility for workers' rights 
As is shown in Figure 1, the firms' responsibilities regarding workers' rights were clearly defined in 1995, and the interpretation span was limited. In essence, the firms were not seen as responsible for workers' rights at their suppliers. FTC successfully challenged this definition in 1996, and the interpretation span was greatly increased. The firms were seen as responsible, but what this meant in practice was vaguely defined. During the first phase (1996-1999), FTC continuously narrowed the interpretation span by establishing and black-boxing 'facts' (in OPP 1-4). The firms were seen as responsible for workers' rights through harmonised codes of conduct and independent monitoring. The narrowing of the interpretation span continued during the second phase (1999-2001), and in 2001 a detailed and documented definition of the garment retailers' responsibilities both in terms of a code and a monitoring system was proposed (in OPP 5-6). In the third phase, the unions challenged this definition and opened close to all black-boxes established in the first and second phase (except the black-boxed 'fact' that retailers are responsible for workers' rights at their suppliers). The interpretation span once again increased, and no actor has since then been able to narrow it. Consequently, currently there is no agreed definition of Swedish garment retailers' responsibilities for workers' rights at their suppliers.

\section{The processes of defining corporate responsibility}

\section{Battles for the right to interpretation}

The conducted study illustrates that the business, union and CSO actors involved in the definition processes had dispersed and often conflicting views and values (cf. Latour, 1996; Callon, 1998b). For example, the firms did not initially want to claim responsibility for workers' rights at their suppliers, while the CSOs and unions wanted them to acknowledge this responsibility; the CSOs and firms wanted codes of conduct while the unions wanted global agreements; and CSOs and unions wanted 'living wages' while the firms wanted 'minimum wages'. Thus, how then can the processes of establishing the definition of corporate responsibility be characterised (research question 1)? For establishing definitions of corporate responsibility, divergence of opinions is problematic since definitions rarely entail much diversity (cf. Callon and Latour 1981; Latour 1999a). Hence, the pluralism of different actors' perceptions has to be silenced when establishing definitions of corporate responsibility. The processes of defining corporate responsibility can therefore be characterised as battles for the right to interpretation. The actors' aim in these battles is to translate and silence other actors, thereby making them refrain from advocating divergent definitions of corporate responsibility.

\section{Actors dictating definition processes}

A central question then becomes: which actors win the battles for the right to interpretation? In other words, which actors grow and dictate the development of the definition processes by enroling and translating other actors (research question 2)? In the first phase of the studied definition processes (1996-1999), the battles were won by FTC. This small organisation directed the development in the Swedish garment retailing industry by translating and setting the agenda for the firms, CSOs and unions. Several 
previous ANT studies indicate similar, at least temporal, success for small actors (e.g. Callon 1986a; Palmås 2005). At first sight this resembles David battling with Goliath and successfully bringing him to his knees. The small organisation FTC, with only one full-time employee, dictated the definition of corporate responsibility for the Swedish garment retailers with over 35,000 employees. However, a closer look reveals that this picture is somewhat distorted. David did not take on Goliath. Rather David grew and became yet another Goliath. FTC increased in strength between 1996 and 1999 through enroling and translating CSOs and unions through the SCCC. In the wording of Callon and Latour (1981), FTC grew into a macro-actor seated on numerous silenced other actors. These silenced actors included such organisations as the Red Cross Youth and influencial unions. By leveraging this network of translated and silenced actors, FTC was able redefine garment retailers' responsibilities from no articulated responsibility for workers' rights to a publicly announced responsibility through harmonised codes of conduct and independent monitoring.

In the second phase (1999-2001), the firms became more successful in their translation efforts and started to act as the Goliath they had the potential to be. However, at this stage they were stuck with the 'facts' that FTC had managed to establish in the first phase, i.e. responsibility through codes of conduct with independent monitoring (cf. Callon 1986a; Selman and Wragg 1999a). The firms' only room of manoeuvre was within these boundaries, and one of the key issues they were able to influence was 'minimum' rather than 'living' wages. In the second phase, the power balance then shifted, and the definition of corporate responsibility was not solely dictated by FTC as it then had to be negotiated between FTC and the firms.

In the third phase (2002-2004), the unions were constrained by the previously established 'facts', and had little choice other than to either accept the 'facts' blackboxed in phase one and two or reverse the definition processes. After several years of being translated, the unions leveraged their resources, and started to direct the redefinition processes by opening previously established black-boxes. Again, similar occurrences and results are frequently noted in previous ANT-studies (e.g. Callon 1986b; Latour 1996). The unions' refusal to allow FTC to speak on their behalf had severely damaged FTC's potential in directing the redefinition processes. The new Goliath, who had built his strength on silenced CSOs and unions, trembled, fell and changed back into a David, i.e. a micro-actor with little ability to influence the processes. After the unions' withdrawal the definition processes lost in momentum in 2002 due to none of the involved organisations being able to dictate the definition processes. Hence, today pluralism remains and no new definition of corporate responsibility seems to emerge.

\section{Exclusionary definition processes}

Besides focusing on the actors directing the definition processes, an ANT framework also highlights the importance of analysing what actors that are excluded from the processes (research question 3). In this study, actors were excluded for two different reasons: some were excluded during the processes and some were not invited to join the processes. The last reason is most strikingly illustrated with the exclusion of employees, unions and organisations in developing countries. These actors, in whose interest the redefinition of responsibility was claimed to have been initiated, were not asked to 
actively participate in the processes (cf. Haraway 1991, 1997; Star 1991). Rather, they were translated and silenced by the Swedish unions, CSOs and firms. During the first and second phase, none of the involved actors seemed to have seriously reflected on the fact that none of the workers, unions and suppliers who were affected by the code of conduct and monitoring was actually involved in the discussions and negotiations. Instead, the Swedish organisations seem to have implicitly perceived themselves as legitimate representatives acting on behalf of these actors.

Secondly, organisations were excluded during the definition processes. For example, SAC Syndicalists was excluded in the second phase of the processes, since the organisation refused to accept the working methods of the partnership that the other CSOs, unions and firms perceived as necessary for a successful collaboration.

These examples illustrate that processes of defining corporate responsibility could be exclusionary processes in which the key actors affected by the developed definition not necessarily are allowed to participate. Finally, the forums (e.g. firm-CSO partnerships) in which the definition processes develop restrict what organisations that want to, and are allowed to, participate.

\section{Concluding remarks}

By introducing Actor-Network Theory as a complementary theoretical approach for studying inter-organisational processes of defining corporate responsibility, this paper provides several contributions to our understanding of how these processes develop. First, it was shown how these processes can be described as battles for the right to interpretation where actors aim to silence pluralism by translating other actors. Second, the study's results illustrated that an initially, and traditionally, non-dominant actor can, at least temporarily, grow and direct the definition processes by translating dominant actors. Due to their position in society, the dominant organisations need to be involved in the processes, but this could be in the form of being translated by small organisations. Third, it was also shown that definition processes do not necessarily develop in democratic and transparent ways, and that key actors affected by the emerging definitions might be excluded from the processes. Finally, the paper also adds to current ANT research by outlining how ANT can be applied in the realm of corporate responsibility and, hence, starts to reveal an unexplored empirical setting for future ANT research. Furthermore, the findings of the conducted study are highly consistent with previous findings in ANT research, indicating that previous ANT findings also are valid in regards to definitions of corporate responsibility.

\section{References}

Ählström J. 2003. A study of corporate adaptation to pressure for corporate social responsibility: an idea network approach. GIN Conference 2003: San Francisco.

Arlow P, Gannon MJ. 1982. Social responsiveness, corporate structure, and economic performance. Academy of Management Review 7(2): 235-241.

Beckert J. 1999. Agency, entrepreneurs, and institutional change: the role of strategic choice and institutionalized practices in organizations. Organization Studies 20(5): 777799. 
Blomquist C. 1996. I marknadens namn. Mångtydiga reformer i svenska kommuner, Nerenius \& Santérus Förlag: Stockholm.

Boons F. 1998. Caught in the web: the dual nature of networks and its consequences. Business Strategy and the Environment 7(4): 204-212.

Callon M. 1986a. Some elements of a sociology of translation: domestication of the scallops and the fishermen of St Brieuc Bay. In Power, Action and Belief, Law J (ed). Routledge \& Kegan Paul: London; 196-233.

Callon M. 1986b. The sociology of an actor-network: the case of the electric vehicle. In Mapping the Dynamics of Science and Technology, Callon M, Latour B, Rip A (eds). Macmillian: London; 19-34.

Callon M. 1998a. Introduction: the embeddedness of economic markets in economics. In The Laws of the Market, Callon M (ed). Blackwell Publishers: Oxford; 1-57.

Callon M. 1998b. An essay on framing and overflowing: economic externalities revisited by sociology. In The Laws of the Market, Callon M (ed). Blackwell Publishers: Oxford; 244-269.

Callon M, Latour B. 1981. Unscrewing the big Leviathan: how actors macro-structure reality and how sociologists help them to do so. In Advances in Social Theory and Methodology: Toward an Integration of Micro- and Macro-Sociologies, Knorr-Cetina K, Cicourel A (eds). Routledge \& Kegan Paul: London; 196-233.

Canning L, Hanmer-Lloyd S. 2001. Managing the environmental adaptation process in supplier-customer relationships. Business Strategy and the Environment 10(4): 225-237.

Carroll AB. 1979. A three-dimensional conceptual model of corporate performance. Academy of Management Review 4(4): 497-505.

Catasús B. 2000. Silent nature becomes normal: a study of environmental reporting. International Studies of Management and Organization 30(3): 59-82.

Clarke S, Roome N. 1999. Sustainable business: learning-action networks as organizational assets. Business Strategy and the Environment 8(5): 296-310.

Cochran PL, Wood RA. 1984. Corporate social responsibility and financial performance. Academy of Management Journal 27(1): 42-56.

Czarniawska B, Hernes T. 2005. Constructing macro actors according to ANT. In Actor-Network Theory and Organizing, Czarniawska B, Hernes T (eds). Copenhagen Business School Press: Copenhagen; 7-13.

Czarniawska B, Sevón G. (eds). 1996. Translating Organizational Change. Walter de Gruyter: Berlin. 
DiMaggio PJ, Powell WW. 1983. The iron cage revisited: institutional isomorphism and collective rationality in organizational fields. American Sociological Review 48(2): 147160.

DiMaggio PJ, Powell WW. 1991. Introduction. In The new institutionalism in organizational analysis, Powell, WW, DiMaggio, PJ (eds). University of Chicago Press: Chicago; 1-38.

Donaldson T, Preston LE. 1995. The stakeholder theory of the corporation: concepts, evidence, and implications. Academy of Management Review 20(1): 65-91.

Egels N. 2005. CSR in electrification of rural Africa: the case of ABB in Tanzania. Journal of Corporate Citizenship 18: 75-85.

Füssel L, Georg S. 2000. The institutionalization of environmental concerns: making the environment perform. International Studies of Management and Organization 30(3): 41-58.

Gladwin TN, Kennelly JJ, Krause TS. 1995. Shifting paradigms for sustainable development: implications for management theory and research. Academy of Management Review 20(4): 874-907.

Gollagher M. 2003. Corporations and the subversive influence of the discourse of sustainability: re-imagining corporate identity. GIN Conference 2003: San Francisco.

Haraway D. 1991. Situated knowledges: the science question in feminism and the privilege of partial perspective. In Simians, Cyborgs and Women: The Reinvention of Nature, Haraway D (ed). Free Association Books: London; 183-201.

Haraway D. 1992. The promises of monsters: a regenerative politics for inappropriate/d others. In Cultural Studies, Grossberg L, Nelson C, Treichler PA (eds). Routledge: New York; 295-337.

Haraway D. 1997.

Modest_Witness@Second_Millenium.Female_Man@_Meets_Oncomouse ${ }^{\mathrm{TM}}$ Feminism and Technoscience. Routledge: London.

Haraway D. 2003. The Companion Species Manifesto: Dogs, People, and Significant Otherness. Prickly Paradigm Press: Chicago.

Harrison D, Easton G. 2002. Collective action in the face of international environmental regulation. Business Strategy and the Environment 11(3): 143-153.

Helgesson C-F, Kjellberg H, Liljenberg A. (eds). 2004. Den där marknaden: Om utbyten, normer och bilder. Studentlitteratur: Lund. 
Hoffman AJ. 1999. Institutional evolution and change: environmentalism and the U.S. chemical industry. Academy of Management Journal 42(4): 351-371.

Hoffman AJ. 2001. From Heresy to Dogma - An Institutional History of Corporate Environmentalism. Stanford University Press: Stanford.

Hoffman AJ, Ventresca MJ. (eds). 2002. Organizations, Policy, and the Natural Environment: Institutional and Strategic Perspectives. Stanford University Press: Stanford, CA.

Holmström J, Robey D. 2005. Understanding IT's organizational consequences: an actor network theory approach. In Actor-Network Theory and Organizing, Czarniawska B, Hernes T (eds). Copenhagen Business School Press: Copenhagen; 165-187.

Ivakhiv A. 2002. Toward a multicultural ecology. Organization \& Environment 15(4): 389-409.

Jennings PD, Zandbergen PA, Martens ML. 2002. Complications in compliance: variation in environmental enforcement in British Columbia's Lower Fraser Basin, 1985-1996. In Organizations, Policy, and the Natural Environment: Institutional and Strategic Perspectives, Hoffman AJ, Ventresca MJ (eds). Stanford University Press: Stanford, CA; 57-89.

Lanzana GF, Morner M. 2005. Artefacts rule! How organizing happens in open-source software projects. In Actor-Network Theory and Organizing, Czarniawska B, Hernes T (eds). Copenhagen Business School Press: Copenhagen; 67-90.

Latour B. 1996. Aramis, or the love of technology. Harvard University Press:

Cambridge, MA.

Latour B. 1999a. Pandora's Hope. Harvard University Press: Cambridge, MA.

Latour B. 1999b. On recalling ANT. In Actor Network Theory and After, Law J, Hassars J (eds). Blackwell Publishers: Oxford; 15-25.

Latour B, Woolgar S. 1979. Laboratory Life: The Social Construction of Scientific Facts. Sage: Beverly Hills, CA.

Law J. 1994. Organizing Modernity. Blackwell: Oxford.

Lee N, Brown S. 1994. Otherness and the actor network: the undiscovered continent, American Behavioral Scientists 3: 772-790.

Maguire S., Hardy C, Lawrence TB. 2004. Institutional entrepreneurship in emerging fields: Hiv/Aids treatment advocacy in Canada. Academy of Management Journal 47(5): 657-679. 
Mähring M, Holmström J, Keil M, Montealegre R. 2004. Trojan actor-networks and swift translation: bringing actor-network theory to IT project escalation studies.

Information Technology and People 17(2): 210-238.

Milstein MB, Hart SL, York AS. 2002. Coercion breeds variation: the differential impact of isomorphic pressure on environmental strategies. In Organizations, Policy, and the Natural Environment: Institutional and Strategic Perspectives, Hoffman AJ, Ventresca MJ (eds). Stanford University Press: Stanford, CA; 151-172.

Morrill C, Owen-Smith J. 2002. The emergence of environmental conflict resolution: subversive stories and the construction of collective action frames and organizational fields. In Organizations, Policy, and the Natural Environment: Institutional and Strategic Perspectives, Hoffman AJ, Ventresca MJ (eds). Stanford University Press: Stanford, CA; 90-118.

Neale A. 1997. Organisational learning in contested environments: lessons from the Brent Spar. Business Strategy and the Environment 6(2): 93-103.

Newton TJ. 2002. Creating the new ecological order? Elias and actor-network theory. Academy of Management Review 27(4): 523-540.

Norén L, Ranerup A. 2005. The Internet web portal as an enrolment device. In ActorNetwork Theory and Organizing, Czarniawska B, Hernes T (eds). Copenhagen Business School Press: Copenhagen; 188-207.

Palmås K. 2005. ReVolvolutions: Innovation, Politics and the Swedish Brand, Unpublished doctoral dissertation. London School of Economics: London.

Porsander L. 2005. "My name is Lifebuoy": an actor-network emerging from action-net. In Actor-Network Theory and Organizing, Czarniawska B, Hernes T (eds). Copenhagen Business School Press: Copenhagen; 14-30.

Rowley T, Berman S. 2000. A brand new brand of corporate social performance. Business \& Society 39(4): 397-418.

Schaefer A, Harvey B. 1998. Stage models of corporate 'greening': a critical evaluation. Business Strategy and the Environment 7(3): 109-123.

Schneiberg M, Clemens ES. 2005. The typical tools for the job: research strategies in institutional analysis. In How Institutions Change, Powell WW, Jones DL (eds). University of Chicago Press: Chicago, IL.

Schwartz B. 1997. Det miljöanpassade företaget: Strategiska uppträdanden på den institutionella scenen. Ph D Thesis. Nerenius \& Santërus Förlag AB: Stockholm.

Scott RW. 1995. Institutions and Organizations. Sage: Beverly Hills, CA. 
Selman P, Wragg A. 1999a. Local sustainability planning: from interest-driven networks to vision-driven super-networks? Planning Practice \& Research 14(3): 329340 .

Selman P, Wragg A. 1999b. Networks of co-operation and knowledge in 'wider countryside' planning. Journal of Environmental Planning and Management 42(5): 649-669.

Star SL. 1991. Power, technologies and the phenomenology of conventions: on being allergic to onions. In A Sociology of Monsters: Essays on Power, Technology and Domination, Law J (ed). Routledge: London and New York; 26-56.

Strannegård L. 2000. Flexible couplings: combining business goals and environmental concerns. Business Strategy and the Environment 9(3): 163-174.

Stubbs M. 2000. Action, knowledge and business-environment research: a case for grounded constitutive process theories and a sense of audience. Business Strategy and the Environment 9(1): 24-35.

Sweet S. 2000. Industrial change towards environmental sustainability: The case of replacing chloroflouorcarbons. EFI: Stockholm.

Van Amerom M. 2002. National sovereignty \& transboundary protected areas in Southern Africa. GeoJournal 58(4): 265-273.

Waddock S, Graves SB. 1997. The corporate social performance-financial performance link. Strategic Management Journal 18(4): 303-319.

Weick KE. 1996. Drop your tools: allegory for organizational studies. Administrative Science Quarterly 41(2): 301-313. 